\title{
TOCOPHEROL LEVEL IN HUMAN BLOOD CELLS
}

\author{
Makoto Mino, Yasuhiko Nishida, Yoshitami KiJima, \\ Mie IwaKoshi, and Shigeo NaKagawa ${ }^{1}$ \\ Department of Pediatrics, Osaka Medical College, \\ Takatsuki, Osaka 569, Japan \\ (Received September 5, 1979)
}

\begin{abstract}
Summary The study was undertaken on alpha-tocopherol levels, separated from other analogs, in the red blood cells (RBC) of cord blood, premature infants, healthy children and adults as well as in pregnant women, and compared with the plasma levels.

1. The majority of tocopherol found in the RBC was localized in the membranes.
\end{abstract}

2. Only alpha-tocopherol was found in the RBC, while alpha- and gamma-tocopherol were found in the plasma.

3. Alpha-tocopherol level in the RBC changes during development in parallel with that in the plasma. However, changes in the level in RBC were smaller than those of the plasma.

4. The ratio of alpha-tocopherol level in the RBC to the plasma was higher in the cord blood and premature infants than in the children and adults.

5. With regard to the cases with high plasma tocopherol levels, a different finding was obtained on the RBC level between pregnant women and adults with a large amount of tocopherol. In the latter, high RBC levels were observed as the plasma levels were elevated, while in spite of a high plasma tocopherol level, the lowest RBC levels were found in the pregnant women.

Keywords alpha-tocopherol, gamma-tocopherol, red blood cell, red blood cell membranes, plasma, HPLC, cord blood, children, adult, pregnant women

It is generally acknowledged that alpha-tocopherol operates to prevent acceleration of oxidative deterioration of biological membranes, where lipid peroxidation may be induced by active oxygen usually metabolized during the cell life $(1,2)$. Although recognition of alpha-tocopherol deficiency is clinically dependent on lowered plasma tocopherol levels and/or an increasing oxidative

1 美濃 真, 西田靖彦, 木島良民, 岩越美恵, 中川茂男 
fragility of red blood cells (RBC) (3-6), it may be, however, more important to know the alpha-tocopherol level in the biological membranes with regard to functional impairment in the deficiency.

With technical advances in tocopherol assay, high-performance liquid chromatography (HPLC) was introduced $(7,8)$, with which a highly sensitive separation and determination of alpha-tocopherol would be expected.

Biological membranes easily obtained from patients are from $\mathrm{RBC}$, which are known to be destroyed in tocopherol deficiency by exposure to oxidative agents, such as hydrogen peroxide $(3-6,9,10)$. Thus, in this paper, a study was undertaken on alpha-tocopherol levels, separated from other analogs, in RBC membranes in cord blood, premature infants, healthy children and adults, as well as in pregnant women, and compared with the plasma tocopherol levels.

\section{MATERIALS AND METHODS}

Cord blood was collected through the umbilical vein or artery after delivery in mature neonates with no complications, and maternal blood was drawn immediately before birth from healthy pregnant women. The blood specimens were obtained from premature infants at 4 to 38 days of age, who had no complications and whose tirth weight was from $1,610 \mathrm{~g}$ to $2,500 \mathrm{~g}$. The other blood specimens were obtained from eight healthy children, 1 to 14 years old (4 males and 4 females), as well as from healthy adults, 24 to 31 years old. The blood specimens in the children and adults were drawn after fasting in the morning.

Three healthy adults were intramuscularly administered with a single dose of $600 \mathrm{mg} d \mathrm{l}$-alpha-tocopheryl acetate, and their blood was drawn at 3 days and 5 days after administration.

Preparation of RBC was carried out by the modified method of Kaydon $(13,14)$ as follows: Fresh blood, $5 \mathrm{ml}$, was transfered directly from a heparinized plastic syringe into the centrifuge tubes containing $0.1 \mathrm{ml}$ of $1 \%$ NaEDTA, and were centrifuged at 2,000 rpm. After being separated from the plasma, the RBC layer was washed three times with 5 volumes of isotonic buffered saline $^{2}$ (pH 7.4) containing EDTA in the same concentration. Then, the final hematocrit of the RBC suspension was made up to about $50 \%$, in which precise $\mathrm{RBC}$ counting and hematocrit measurement was carried out.

Preparation of RBC membranes was performed by the method of DODGE (12).

The procedure of extraction of tocopherol and of HPLC by a minor modification of ABE's method (7) was as follows: $0.5 \mathrm{ml}$ of plasma was placed into a glass-stoppered $12-\mathrm{ml}$ centrifuge tube, into which $0.5 \mathrm{ml}$ of distilled water and $1 \mathrm{ml}$ of tocol solution $(2 \mu \mathrm{g} / \mathrm{ml}$ ethanol) were added. After vigorous shaking, $5 \mathrm{ml}$ of $n$ hexane was added and was shaken again for $1 \mathrm{~min}$. The mixture was centrifuged at $1,000 \mathrm{rpm}$ for $5 \mathrm{~min}$, and $4 \mathrm{ml}$ of hexane layer was evaporated under nitrogen gas

2 The buffer solution was prepared in a mixture of the same volume of $0.15 \mathrm{M}$ phosphate buffer and $n$-saline. 
flow at $40^{\circ} \mathrm{C}$. The residue was dissolved in $50 \mu$ l of hexane, in which $20 \mu \mathrm{l}$ was injected into the HPLC column.

With regard to alpha-tocopherol determination in $\mathrm{RBC}$ or $\mathrm{RBC}$ membranes, $0.5 \mathrm{ml}$ of an $\mathrm{RBC}$ suspension or RBC membrane suspension was placed into the centrifuge tube where $1 \mathrm{ml}$ of $6 \%$ pyrogallol solution in ethanol and the same volume of tocol solution as described above and $0.2 \mathrm{ml}$ of $60 \% \mathrm{KOH}$ were added, and the tube was incubated at $70^{\circ} \mathrm{C}$ for $30 \mathrm{~min}$ for saponification. After cooling, $2.5 \mathrm{ml}$ of water and $5 \mathrm{ml}$ of hexane were added to the tube, then extraction into the hexane layer was performed in the same manner as the preparation of plasma tocopherol.

The instruments used in this study were as follows: HPLC: FLC-350 (Japan Spectroscopic Co., Ltd.), Column: JASKOPACK-WC-03-500 (Partition, $2.3 \mathrm{~mm}$ i.d. $\times 500 \mathrm{~mm})$, Detector: Fluorospectrophotometer, JASKO FP-4 type (Ex. $298 \mathrm{~nm}$, Em. $325 \mathrm{~nm}$ ) or Spectrophotometer, JASKO UVIDEC -2 type $(295 \mathrm{~nm})$. Solvent: Isopropylether $/ n$-hexane $=0.5 / 99.5$. Flow rate; $1.0 \mathrm{ml} / \mathrm{min}$.

Retention time was $2.2 \mathrm{~min}$ for alpha-, $3.8 \mathrm{~min}$ for beta-, $4.6 \mathrm{~min}$ for gamma-, $6.9 \mathrm{~min}$ for delta-tocopherol and $10.0 \mathrm{~min}$ for tocol, respectively.

\section{RESULTS}

Pattern of tocopherols detected by HPLC analysis are shown in Fig. 1. Alphaand gamma-tocopherol were detected in the $0.2 \mathrm{ml}$ of plasma, while only the alpha form was detected in the $\mathrm{RBC}$ as well as in the $\mathrm{RBC}$ membranes corresponding to the $0.25 \mathrm{ml}$ of packed cells.

Table 1 shows the recovery test of alpha-tocopherol in the specimens. A satisfactory result was obtained in the recovery of alpha-tocopherol added to the plasma and RBC.

Alpha-tocopherol levels analyzed from the total RBC were compared with those from membranes prepared by the method of Dodge. As shown in Table 2, similar tocopherol levels were observed in both. This finding indicates that the majority of tocopherol is localized in the membranes. Thus, further examination was carried out in the determination from total RBC, owing to the technical complexity of membrane preparation.

The four cord blood specimens were separately collected through the umbilical vein and artery, and the alpha-tocopherol levels were compared. As shown in Table 3 , similar results were obtained in the plasma and in the RBC. Hence, other cord blood was drawn only through the umbilical vein.

Table 4 shows the level of plasma and RBC in the cord blood as compared with the mother's. It was surprising that no significant difference was observed in the two levels of RBC, while in the plasma the mother's level was higher than in the cord blood.

The level of plasma and $\mathrm{RBC}$ in premature infants, healthy children and adults are shown in Tables 5, 6 and 7, respectively. From the results, changes in the 

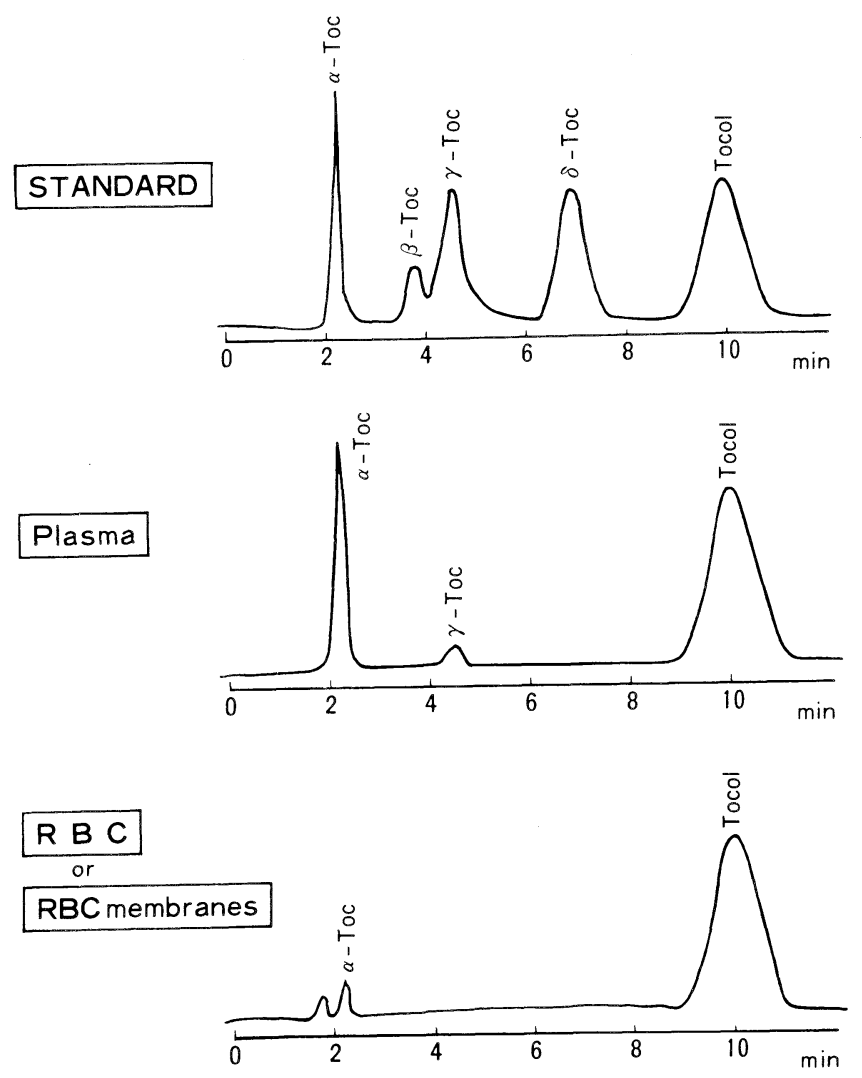

Fig. 1. Patterns of tocopherols isolated by HPLC in the standard, plasma and RBC (or their membranes).

Retention time of tocopherols: $\alpha$-Toc, $2.2 \mathrm{~min} ; \beta$-Toc, $3.8 \mathrm{~min} ; \gamma$-Toc, $4.6 \mathrm{~min} ; \delta$-Toc, $6.9 \mathrm{~min}$; Tocol, $10.0 \mathrm{~min}$.

Table 1. Result of recovery test in the assay procedure for alpha-tocopherol in the plasma and RBC.

\begin{tabular}{crcrc}
\hline \multicolumn{3}{c}{ Alpha-tocopherol level $(\mu \mathrm{g})$} & Recovery $(\%)$ \\
\cline { 1 - 2 } Specimen & Added & Theoretical & Determined & \\
\hline (Plasma) & & & & \\
8.65 & 5.00 & 13.65 & 13.60 & 99.6 \\
8.65 & 10.00 & 18.65 & 18.88 & 102.3 \\
9.97 & 5.00 & 14.97 & 15.21 & 104.4 \\
9.97 & 10.00 & 19.97 & 20.19 & \\
$(\mathrm{RBC})$ & & & & 92.6 \\
1.76 & 5.00 & 6.76 & 6.39 & 103.2 \\
1.75 & 10.00 & 11.76 & 12.07 & 102.7 \\
1.30 & 10.00 & 11.30 & 11.57 & 101.2 \\
1.23 & 5.00 & 6.23 & 6.29 & \\
\hline
\end{tabular}


Table 2. Alpha-tocopherol level in RBC membranes as compared with that in total RBC.

\begin{tabular}{ccc}
\hline No. & RBC & RBC membrane \\
& $\begin{array}{c}(\mathrm{mg} / \mathrm{d} l \cdot \mathrm{RBC}) \\
(\text { as packed cell })\end{array}$ & $\begin{array}{c}(\mathrm{mg} / \mathrm{memb} \text { (mes in the } \\
\text { same volume of } \mathrm{RBC})\end{array}$ \\
\hline 1 & 0.25 & 0.21 \\
2 & 0.15 & 0.19 \\
3 & 0.15 & 0.19 \\
5 & 0.26 & 0.20 \\
\hline mean \pm SD & 0.36 & 0.34 \\
\hline
\end{tabular}

RBC membranes prepared by the method of Dodge were saponified and lipids were eluted with $n$-hexane by the same procedure for RBC assay.

Table 3. Comparison of alpha-tocopherol level between venous and arterial blood drawn from umbilical cords.

\begin{tabular}{|c|c|c|c|c|c|c|}
\hline \multirow{3}{*}{ No. } & \multicolumn{3}{|c|}{ Venous blood } & \multicolumn{3}{|c|}{ Arterial blood } \\
\hline & \multirow{2}{*}{$\begin{array}{l}\text { Plasma } \\
(\mathrm{mg} / \mathrm{dl})\end{array}$} & \multicolumn{2}{|c|}{$\mathrm{RBC}$} & \multirow{2}{*}{$\begin{array}{l}\text { Plasma } \\
(\mathrm{mg} / \mathrm{dl})\end{array}$} & \multicolumn{2}{|c|}{$\mathrm{RBC}$} \\
\hline & & $\begin{array}{c}(\mathrm{mg} / \mathrm{dl} \cdot \mathrm{RBC}) \\
(\text { as packed cell) }\end{array}$ & $\left(\mathrm{ng} / 10^{8} \cdot \mathrm{RBC}\right)$ & & $\begin{array}{c}(\mathrm{mg} / \mathrm{dl} \cdot \mathrm{RBC}) \\
(\text { as packed cell) }\end{array}$ & $\left(\mathrm{ng} / 10^{8} \cdot \mathrm{RBC}\right)$ \\
\hline 1 & 0.28 & 0.16 & 18.4 & 0.29 & 0.15 & 16.4 \\
\hline 2 & 0.40 & 0.15 & 15.4 & 0.47 & 0.18 & 18.6 \\
\hline 3 & 0.40 & 0.12 & 11.9 & 0.40 & 0.16 & 16.9 \\
\hline 4 & 0.43 & 0.12 & 12.0 & 0.43 & 0.12 & 12.2 \\
\hline mean $\pm \mathrm{SD}$ & $0.38 \pm 0.07$ & $0.14 \pm 0.02$ & $14.4 \pm 3.1$ & $0.40 \pm 0.08$ & $0.15 \pm 0.03$ & $16.0 \pm 2.7$. \\
\hline
\end{tabular}

$\mathrm{RBC}$ counting was carried out from a $50 \%$ suspension made up after washing.

levels in the plasma and RBC during development are shown in Fig. 2. Alphatocopherol levels in the RBC changed in parallel with those in the plasma during development. However, changes in the level of $\mathrm{RBC}$ were smaller than those of the plasma during development. Accordingly, the ratio of the level in RBC to that in plasma was observed in the cord blood, premature infants, children and adults, and was compared with that of pregnant women, as shown in Fig. 3. The ratio was higher in the cord blood and premature infants than in the children and adults. The lowest occurred in the pregnant women. This finding suggests that plasma tocopherol level don't directly reflect the level in RBC membranes. Then, whether 
Table 4. Alpha-tocopherol level in RBC of maternal and cord blood as compared with that in plasma.

\begin{tabular}{|c|c|c|c|c|c|c|}
\hline \multirow{3}{*}{ No. } & \multicolumn{3}{|c|}{ Maternal blood } & \multicolumn{3}{|c|}{ Cord blood } \\
\hline & \multirow{2}{*}{$\begin{array}{l}\text { Plasma } \\
(\mathrm{mg} / \mathrm{dl})\end{array}$} & \multicolumn{2}{|c|}{$\mathrm{RBC}$} & \multirow{2}{*}{$\begin{array}{l}\text { Plasma } \\
(\mathrm{mg} / \mathrm{dl})\end{array}$} & \multicolumn{2}{|c|}{$\mathrm{RBC}$} \\
\hline & & $\begin{array}{c}(\mathrm{mg} / \mathrm{dl} \cdot \mathrm{RBC}) \\
\text { (as packed cell) }\end{array}$ & $\left(\mathrm{ng} / 10^{8} \cdot \mathrm{RBC}\right)$ & & $\begin{array}{c}(\mathrm{mg} / \mathrm{dl} \cdot \mathrm{RBC}) \\
(\text { as packed cell) }\end{array}$ & $\left(\mathrm{ng} / 10^{8} \cdot \mathrm{RBC}\right)$ \\
\hline 1 & 1.70 & 0.17 & 9.2 & 0.28 & 0.16 & 18.4 \\
\hline 2 & 2.11 & 0.17 & 15.6 & 0.40 & 0.15 & 15.4 \\
\hline 3 & 2.30 & 0.18 & 14.7 & 0.40 & 0.12 & 11.9 \\
\hline 4 & 2.25 & 0.14 & 11.9 & 0.43 & 0.12 & 12.0 \\
\hline 5 & 1.16 & 0.18 & 13.3 & 0.46 & 0.21 & 21.2 \\
\hline 6 & 2.99 & 0.20 & 16.1 & 0.40 & 0.19 & 20.6 \\
\hline 7 & 1.56 & 0.22 & 21.8 & 0.39 & 0.19 & 20.2 \\
\hline mean $\pm \mathrm{SD}$ & $2.01 \pm 0.60$ & $0.18 \pm 0.03$ & $14.7 \pm 3.9$ & $0.39 \pm 0.06$ & $0.16 \pm 0.04$ & $17.1 \pm 4.0$ \\
\hline
\end{tabular}

The correlation is shown between simultaneous maternal and cord blood.

Table 5. Alpha-tocopherol levels in RBC and plasma of premature infants.

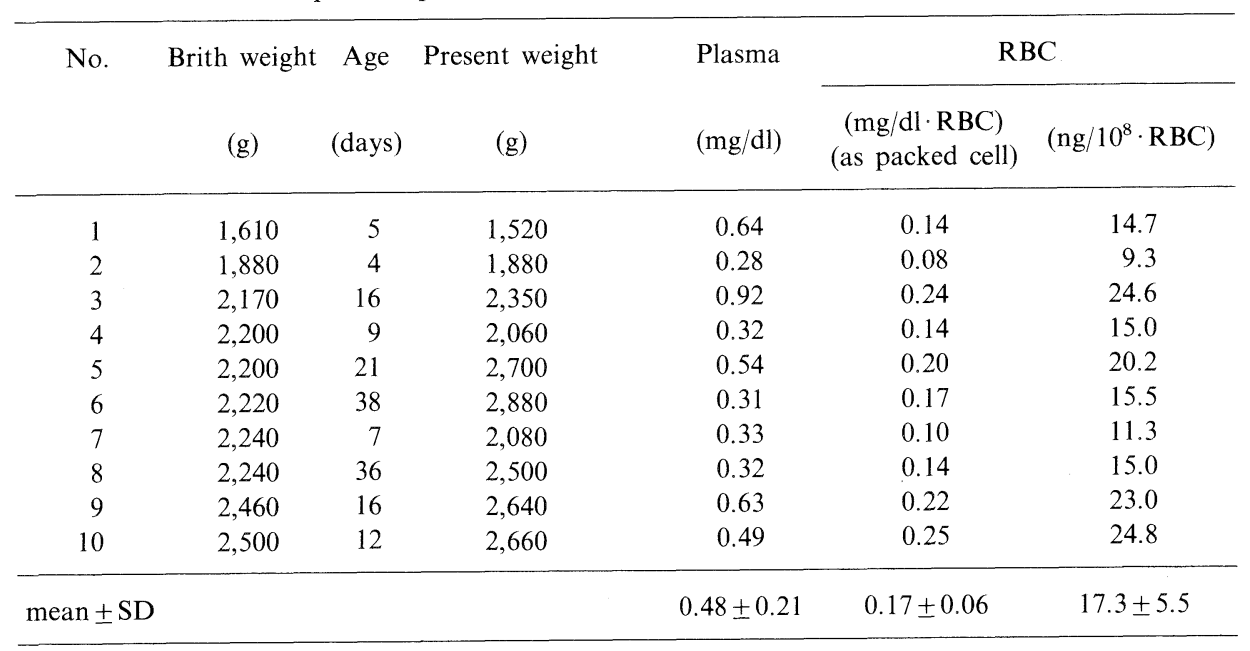

Blood was drawn immediately before feeding ( 3 hours' fasting).

alpha-tocopherol level in the RBC is influenced as the plasma level is elevated by an administration of a large amount of tocopherol, was examined.

Administration of tocopheryl acetate was carried out under the conditions described above. Since a small amount of tocopheryl acetate is known to remain in 
Table 6. Alpha-tocopherol levels in RBC and plasma of the children.

\begin{tabular}{|c|c|c|c|c|c|}
\hline \multirow[t]{2}{*}{ No. } & \multirow{2}{*}{$\begin{array}{l}\text { Age } \\
\text { (Yrs.) }\end{array}$} & \multirow[t]{2}{*}{ Sex } & \multirow{2}{*}{$\begin{array}{l}\text { Plasma } \\
(\mathrm{mg} / \mathrm{dl})\end{array}$} & \multicolumn{2}{|c|}{$\mathrm{RBC}$} \\
\hline & & & & $\begin{array}{l}(\mathrm{mg} / \mathrm{dl} \cdot \mathrm{RBC}) \\
\text { (as packed cell) }\end{array}$ & $\left(\mathrm{ng} / 10^{8} \cdot \mathrm{RBC}\right)$ \\
\hline 1 & 1 & $\mathbf{M}$ & 0.96 & 0.35 & 26.7 \\
\hline 2 & 6 & $\mathrm{M}$ & 0.84 & 0.19 & 15.4 \\
\hline 3 & 9 & $\mathrm{M}$ & 0.97 & 0.28 & 22.1 \\
\hline 4 & 12 & $\mathrm{M}$ & 1.05 & 0.24 & 23.9 \\
\hline 5 & 3 & $\mathrm{~F}$ & 1.05 & 0.22 & 18.1 \\
\hline 6 & 7 & $\mathrm{~F}$ & 0.82 & 0.15 & 15.2 \\
\hline 7 & 12 & $\mathrm{~F}$ & 1.01 & 0.25 & 26.1 \\
\hline 8 & 14 & $\mathrm{~F}$ & 0.53 & 0.15 & 15.6 \\
\hline mean $\pm \mathrm{SD}$ & & & $0.90 \pm 0.17$ & $0.23 \pm 0.07$ & $20.4 \pm 4.9$ \\
\hline
\end{tabular}

Blood was drawn after overnight fasting.

Table 7. Alpha-tocopherol levels in RBC and plasma of healthy adults.

\begin{tabular}{rccc}
\hline \multirow{2}{*}{ No. } & Plasma & \multicolumn{2}{c}{$\mathrm{RBC}$} \\
\cline { 3 - 4 } & $(\mathrm{mg} / \mathrm{d} 1)$ & $(\mathrm{mg} / \mathrm{dl})($ as packed cell $)$ & $\left(\mathrm{ng} / 10^{8} \cdot \mathrm{RBC}\right)$ \\
\hline 1 & 0.87 & 0.24 & 22.7 \\
2 & 1.32 & 0.15 & 13.4 \\
3 & 0.76 & 0.17 & 15.3 \\
4 & 0.60 & 0.17 & 15.9 \\
5 & 0.99 & 0.24 & 21.0 \\
6 & 0.58 & 0.18 & 17.6 \\
7 & 0.83 & 0.17 & 13.9 \\
8 & 0.73 & 0.19 & 15.2 \\
9 & 0.75 & 0.18 & 18.8 \\
10 & 0.68 & 0.19 & 16.3 \\
11 & 0.82 & 0.20 & 30.8 \\
\hline 2 & 1.20 & 0.31 & $18.0 \pm 4.9$ \\
\hline
\end{tabular}

Blood was drawn after overnight fasting.

the plasma for more than 24 hours after intramuscular administration (21), the assay of tocopherol in the plasma was performed by the same method with saponification as for RBC assay. Results are shown in Table 8. With increased plasma tocopherol levels after loading, the levels in RBC were also elevated, while 

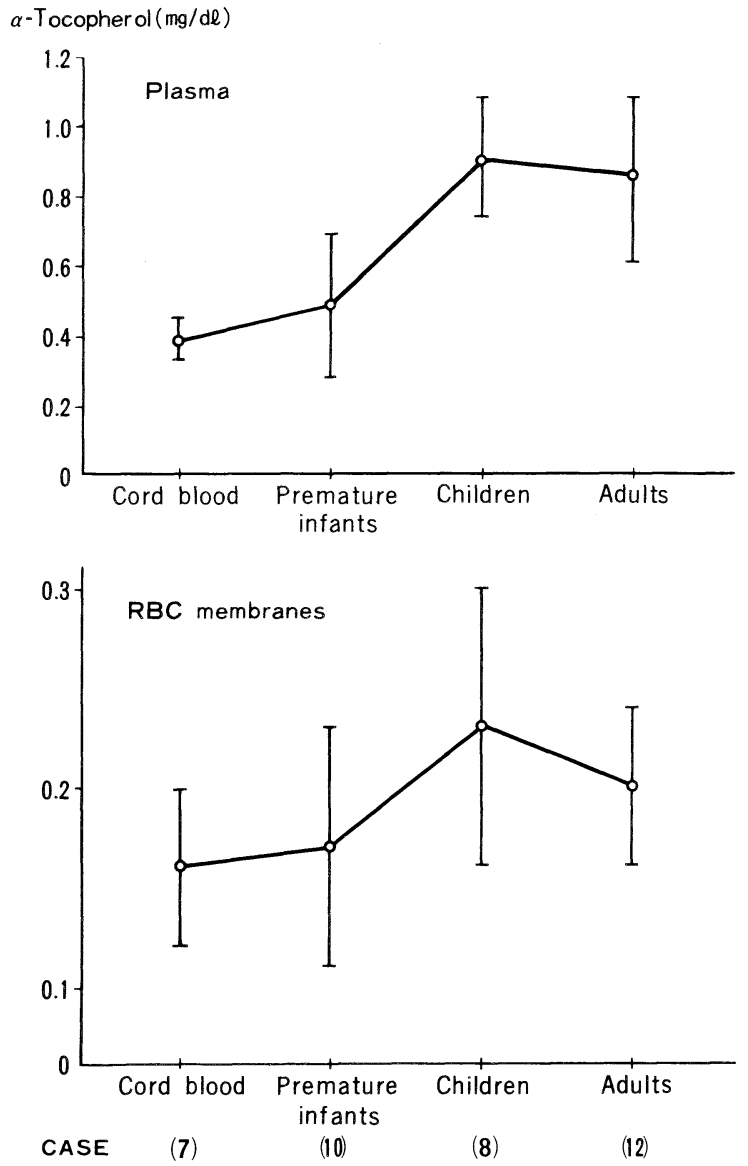

Fig. 2. Changes in alpha-tocopherol levels in plasma and RBC during development. Mean values \pm SD shown in the figure result from the values in Tables 4 to 7 .

the ratios of alpha-tocopherol in $\mathrm{RBC}$ to plasma were nearly constant even when the blood tocopherol level was elevated.

\section{DISCUSSION}

There have been few investigations into alpha-tocopherol levels in $\mathrm{RBC}$ owing to technical difficulties of the assay. In previous reports $(11,13,14)$, the assay was carried out using TLC and/or GLC techniques, and in association, further correction, calculated from the recovery of isotope-labeled tocopherol added at the beginning of procedure, was necessary. The method introducing HPLC, as devised by $\operatorname{Abe}(7)$ and Ishibashi (8), was used in our study; this gave a simple 


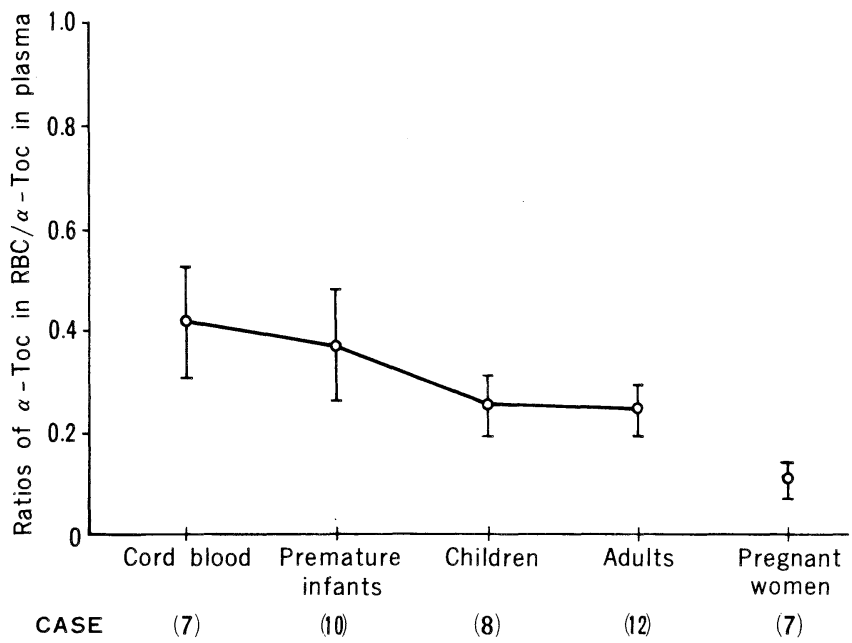

Fig. 3. Changes in the ratios of alpha-tocopherol in RBC to that in plasma during development, and compared with the ratios in pregnant women.

Mean values \pm SD shown in the figure were calculated from the values in Tables 4 to 7 . Tocopherol levels of RBC used for calculation were the values per packed cell.

Table 8. Changes in alpha-tocopherol level of RBC and plasma after the intramuscular administration of a large amount of $d l$-alpha-tocopheryl acetate.

\begin{tabular}{|c|c|c|c|c|c|c|}
\hline \multirow{2}{*}{ Case } & \multirow{2}{*}{ Age } & \multirow{2}{*}{ Sex } & & \multicolumn{2}{|c|}{ Alpha-tocopherol } & \multirow{2}{*}{$\begin{array}{l}\text { Tocopherol ratio } \\
\text { of } \mathrm{RBC} \text { to plasma }\end{array}$} \\
\hline & & & & Plasma $(\mu \mathrm{g} / \mathrm{dl})$ & $\operatorname{RBC}(\mu \mathrm{g} / \mathrm{dl})$ & \\
\hline \multirow[t]{3}{*}{1} & 32 & M & Before & 651 & 180 & 27.6 \\
\hline & & & After (3 days) & 1,420 & 419 & 29.5 \\
\hline & & & (5 days) & 981 & 251 & 25.5 \\
\hline \multirow[t]{3}{*}{2} & 29 & M & Before & 605 & 143 & 23.6 \\
\hline & & & After (3 days) & 1,308 & 419 & 32.0 \\
\hline & & & (5 days) & 1,052 & 286 & 27.1 \\
\hline \multirow[t]{3}{*}{3} & 29 & $\mathrm{~F}$ & Before & 891 & 263 & 29.5 \\
\hline & & & After (3 days) & 1,851 & 523 & 28.2 \\
\hline & & & (5 days) & 1,255 & 365 & 29.0 \\
\hline
\end{tabular}

Intramuscular administration with a single dose of $600 \mathrm{mg}$ of $d l$-alpha-tocopheryl acetate was performed. Blood was drawn at 3 days and 5 days after the administration. The assay for plasma was carried out with the treatment of saponification, since a small amount of the tocopheryl acetate administered may remain in the plasma.

procedure, and also high sensitivity and reproducibility for tocopherol assay in the $\mathrm{RBC}$, in which 10 or $15 \%$ of tocopherol in the whole blood was detected. Thus, 
correction based on recovery was unnecessary, as almost $100 \%$ recovery was directly obtained.

With regard to plasma tocopherol, we obtained similar results to those reported by $\mathrm{ABE}(15)$; more than $85 \%$ of the total tocopherol was the alpha form, but only a small amount of the gamma form was detected, while no beta- or delta-tocopherol was detected.

With regard to $\mathrm{RBC}$ tocopherol, only the alpha form was detected in our study, while CHAw (16) and IsHIBASHI (8) detected the alpha form, which accounted for the majority of the total tocopherol, and a much smaller amount of the gamma form. Since the alpha-tocopherol level in the RBC in our study was similar to that reported by Ishibashi, no detection of the gamma form is possibly due to too small an amount of RBC being used for our assay.

The finding that alpha-tocopherol is localized only in the membranes of RBC, is in agreement with CHOw (16) and SILBER (14). CHOw used direct measurement of RBC membranes, while SILBER used isotope-labeled tocopherol.

Investigation of tocopherol in human RBC was carried out by BIERI(17) and $\operatorname{KaYdON}(13,14)$. The level given by Bieri is coincident with ours, while Kaydon's is slightly lower. The difference in the levels was not significant.

IsHIBASHI (8) reported that the ratio of tocopherol in RBC to plasma differs between animal species, but is relatively constant within the same species, even if the tocopherol level is increased by supplement. Ishibashi's results suggest that the plasma tocopherol level reflects the level in membranes. As shown in Table 8, when the tocopherol level in plasma is elevated by loading, a rise of its level in the RBC reflected the plasma level. This finding is in agreement with Ishibashi's view. In contrast, the ratio differed with human development, as well as in the pregnant women in our study. The difference of the ratios during development resulted from the fact that the rise of the level in $\mathrm{RBC}$ was much smaller than that in the plasma, i.e., $\mathrm{RBC}$ membranes in the cord blood and premature infant with the lowest plasma level maintained their tocopherol level. Such a relationship between the plasma and RBC tocopherol levels has been indicated in the cases with abetalipoproteinemia as reported by $\operatorname{BIERI}(11)$.

The finding of a low RBC level in spite of a high plasma level in pregnant women, while with loading a large amount of tocopherol there was a high level in the plasma as well as in RBC, could not adequately be interpreted. $\operatorname{BIERI}(17,18)$ proposed that a distribution of tocopherol in the components of the body is due to a mass action effect of the lipids, e.g. it may be distributed simply in the lipid mass of body components such as adipose tissues, plasma lipids, lipoproteins and membrane lipids, etc. The hypothesis is based on the finding (18) that in obese rats with hyperlipemia, although the plasma tocopherol was elevated, the tissue tocopherol content was lower than in normolipemic, nonobese rats. It also derives from the additional finding (17) that RBC content of tocopherol decreased as plasma lipid increased when the distribution of isotope-labeled tocopherol in the in vitro reaction system between the plasma, which was experimentally made on hypo- 
and hyperlipemia, and RBC was examined. The recent report by MACHLIN (19) may reflect Bieri's view, that in a guinea pig alternately fed a diet with and without vitamin $\mathrm{E}$ histological evidence of a vitamin E deficiency (myopathy) appeared at the time when adipose tocopherol stores were not significantly different from the initial values. These findings suggest that the various lipid pools in the body act as a "sink" for tocopherol and can drastically affect how the various nonlipid tissues take up the vitamin. Thus, tocopherol taken up into a large lipid mass may lose the function for transport to other components and for exchange between the lipid phases.

From this standpoint, it thus appears that in order to interpret how tocopherol levels in plasma relate to the membrane status of vitamin E, it is necessary to take into consideration the degree of adiposity of the body components, as emphasized by Bieri.

With regard to maternal lipid metabolism, it is well known that lipid stores in maternal adipose tissues increase over the first two-thirds of gestation, while toward the end of pregnancy lipolysis in adipose tissue increases and circulating FFA concentration rises (20). Thus, the point arising as to whether uptake of tocopherol occurs more predominantly into the circulating lipids than into the $\mathrm{RBC}$ membranes in the pregnant women, remains to be studied.

From the standpoint regarding the membrane action of tocopherol, it may be of dubious value to take into consideration that the biological importance of tocopherol in the membranes is regulated and maintained only by its distribution among the lipid phases in the body components. Further study is required to elucidate this problem.

This study was supported by Grant No. 148203 in aid for Scientific Research, Japan.

We thank Dr. G. Katsui for exchange of ideas during the course of this work, and Mr. K. Abe for his continuing help in preparing the HPLC analysis.

\section{REFERENCES}

1) MCCay, P. B., Fong, K. -L., and King, M. M. (1978): Possible role of vitamin E as free radical scavenger and singlet oxygen quencher effect in biological systems which initiate radical mediated reactions, in Tocopherol, Oxygen and Biomembranes, Elsevier, Amsterdam, pp. 41-57.

2) Mino, M., and Sugita, K. (1978): The membrane action of alpha-tocopherol upon oxidative damage in erythrocytes, in Tocopherol, Oxygen and Biomembranes, Elsevier, Amsterdam, pp. 71-81.

3) Blumberg, R. W., Forbes, G. B., Fraser, A. E., Lowe, C. U., Smith, N. J., Sweeney, M. J., and Fomon, S. J. (1963): American Academy of Pediatrics, Report of the Commitee on Nutrition, Vitamin E in Human Nutrition. Pediat., 31, 324-328.

4) Horwitt, M.K., Harvey, C.C., and Harmon, E. M. (1968): Lipids, alpha-tocopherol and erythrocyte hemolysis. Vitamin. Hormon., 26, 487-499.

5) Chadd, M.A., and Fraser, A.J. (1971): A controlled trial of vitamin E therapy in infancy. Internat. J. Vitam. Res., 40, 610-616.

6) Lo, S. S., Frank, D., and Hitzig, W. H. (1973): Vitamin E and haemolytic anemia in premature infants. Arch. Dis. Child., 48, 360-365. 
7) Abe, K., Yuguchi, Y., and Katsui, G. (1975): Quantitative determination of tocopherols by High Speed Liquid Chromatography. J. Nutr. Sci. Vitaminol., 21, 183-188.

8) Ishibashi, K., Abe, K., Ohmae, M., Kawabe, Y., and Katsui, G. (1977): Determination of tocopherols in red blood cells by High Speed Liquid Chromatography. Vitamins (in Japanese), 51, 415-422.

9) Brin, M., Horn, L. R., and BARKer, M. O. (1974): Relationship between fatty acid composition of erythrocytes and susceptibility to vitamin E deficiency. Am. J. Clin. Nutr., 27, 945-951.

10) Mino, M., Nishida, Y. Murata, K., Takegawa, M., Katsui, G., and Yuguchi, Y. (1978). Studies on the factors influencing the hydrogen peroxide hemolysis test. J. Nutr. Sci. Vitaminol., 24, 383-395.

11) Bieri, J.G., and PoukKa, R. K.H. (1970): Red cell content of vitamin E and fatty acids in normal subjects and patients with abnormal lipid metabolism. Internat. J. Vitam. Res., 40, 344-335.

12) Dodge, J.T., Michell, C., and Hanahan, D. J. (1963): The preparation and chemical characteristics of hemoglobin-free ghosts of human erythrocytes. Arch. Biochem. Biophys., 100, $119-130$.

13) Kaydon, H.J., and BJornson, L. (1972): The dynamics of vitamin E transport in the human erythrocyte. Ann. N.Y. Acad. Sci., 203, 127-140.

14) Silber, R., Winter, R., and Kaydon, H.J. (1969): Tocopherol transport in the rat erythrocyte. J. Clin. Invest., 48, 2089-2095.

15) ABe, K., and Katsui, G. (1975): Determination of tocopherols in serum by High-Speed Liquid Chromatography. Vitamins (in Japanese), 49, 259-263.

16) CHow, K.C. (1975): Distribution of tocopherols in human plasma and red blood cells. Am. J. Clin. Nutr., 28, 756-760.

17) Bieri, J. G., Poukka, R., and Thorp, S. (1977): Factors affecting the exchange of tocopherol between red blood cells and plasma. Am. J. Clin. Nutr., 30, 686-690.

18) BiERI, J. G., and PoukKA, R. (1975): Effect of plasma lipids and obesity on tissue stores of alphatocopherol. Proc. Soc. Exp. Biol. Med., 149, 500-502.

19) Machlin, L. J., Keating, J., Nelson, J., Brin, M., Filipski, R., and Miller, O. N. (1979): Availability of adipose tissue tocopherol in the guinea pig. J. Nutr., 109, 105-109.

20) Hull, D. (1976): Fetal fat metabolism, in Fetal Physiology and Medicine, ed. by Beard, R. W. and Nathanielsz, P. W., Sounders Co., London, pp. 105-120.

21) Fuji, T., Terai, Y., Hatakeyama, T., and Wako, H. (1979): Changes in tocopherols in blood by the parenteral administration with $d l$-alpha-tocopheryl acetate (Abstract), Vitamins (in Japanese), 53, 407 . 